\title{
Physical exercise on serum electrolytes and acid base balance in Mangalarga Marchador horses submitted to cavalcade of 4, 8 and $20 \mathrm{~km}$
}

\author{
Jessica Martins Linhares ${ }^{1}$ Paula Alessandra Di Filippo ${ }^{1 *}$ Paulo Moreira Bogossian $^{1}$ \\ Rafael Vianna Barbosa de Almeida Guerra ${ }^{1}$ Sebastian Ricardo Bustamante Bustamante ${ }^{1}$ \\ Cláudio Baptista de Carvalho $^{1}$ Felipp da Silveira Ferreira ${ }^{1}$
}

\footnotetext{
${ }^{1}$ Laboratório de Clínica e Cirurgia Animal (LCCA), Centro de Ciências e Tecnologias Agropecuárias (CCTA), Universidade Estadual do Norte Fluminense. "Darcy Ribeiro" (UENF), Avenida Alberto Lamego, 2000, 28013-602, Campos dos Goytacazes, RJ, Brasil. E-mail: pdf@uenf.br. "Corresponding author.
}

\begin{abstract}
Acid-base and electrolyte disorders have been described in horses associated during and after exercise. The aim of the present study was to evaluate the effect of cavalcade competition on the acid-base and hydroelectrolytic balance in Mangalarga Marchador horses. For this purpose, 15 geldings, $6.2 \pm 1.2$ years old and clinically healthy, were distributed into three groups of five animals each. Horses were trained to take part in cavalcade competitions. Animals were submitted to cavalcade along $4 \mathrm{~km}(G 4), 8 \mathrm{~km}(G 8)$, and $20 \mathrm{~km}(\mathrm{G} 20)$ at mean speeds of $15 \mathrm{~km} h^{-1}, 12 \mathrm{~km} \mathrm{~h} h^{-1}$, and $12 \mathrm{~km} h^{-1}$, respectively. From each horse, venous blood samples were collected before exercise (TO) and immediately after (T1) cavalcade. Bicarbonate ion (HCO -), pH, partial pressure of carbon dioxide $\left(\mathrm{pCO}_{2}\right)$, partial pressure of oxygen ( $\left.\mathrm{PO}_{2}\right)$, base excess $(\mathrm{BE})$, hematocrit $(\mathrm{Hct})$, sodium $(\mathrm{Na}+)$, potassium $(\mathrm{K}+)$, chloride $(\mathrm{Cl}-)$ and lactate were determined. The variables $\mathrm{pH}, \mathrm{pO}$ and $\mathrm{pCO}$, were corrected in function of rectal temperature of each animal. Blood samples were analyzed for acid-base balance, as well as biochemical and electrolyte parameters using an i-STAT analyzer. Significant $(P<0.05)$ increase in $\mathrm{Hct}, \mathrm{Na}^{+}, \mathrm{pH}, \mathrm{HCO}{ }_{3}^{-}$and $\mathrm{BE}$ were observed after cavalcade in $G 20$ group. Decrease $(P<0.05)$ in $K^{+}$and $C l$ were also observed in $G 20$ animals after cavalcade $(T 1)$. Changes in the acidbase balance and hydroelectrolytic profile of the Mangalarga Marchador after cavalcade of $20 \mathrm{~km}$ resulted in hypochloremic metabolic alkalosis. The $20 \mathrm{~km}$ cavalcade induced significant hydroelectrolytic and acid-base imbalances in Mangalarga Marchador horses.
\end{abstract}

Key words: blood gas, electrolytes, equines, acidosis, alkalosis, cavalcade.

Influência do exercício físico sobre o equilíbrio ácido base e hidroeletrolítico em cavalos da raça Mangalarga Marchador submetidos a provas de cavalgadas de 4, 8 e $20 \mathrm{~km}$

RESUMO: Distúrbios ácido-base e eletrolíticos têm sido descritos em cavalos durante e após diferentes modalidades de exercícios. Este estudo foi realizado com o objetivo de investigar o efeito do esforço fisico de cavalgada sobre o equilíbrio ácido base e hidroeletrolítico de cavalos da raça Mangalarga Marchador. Quinze cavalos castrados com média de idade de 6.2 1.2 anos foram distribuídos em três grupos com 05 indivíduos cada.

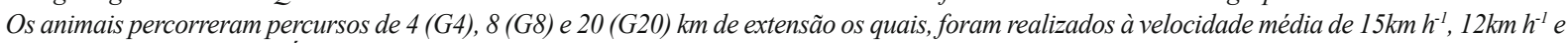
$12 \mathrm{~km} \mathrm{~h}^{-1}$, respectivamente. Ín bicarbonato $\left(\mathrm{HCO}_{3}^{-}\right), \mathrm{pH}$, pressão parcial de dióxido de carbono $\left(\mathrm{pCO} \mathrm{C}_{2}\right)$, pressão parcial de oxigênio $\left(\mathrm{p} \mathrm{O}_{2}\right)$, excesso de bases (BE), hematócrito ( $\mathrm{Hct}$ ), sódio $(\mathrm{Na}+)$, potássio $(\mathrm{K}+)$, cloreto (Cl-) e lactato foram mensurados. As variáveis $\mathrm{pH}, \mathrm{pO}_{2}$ e $\mathrm{pCO} \mathrm{C}_{2}$ foram corrigidas em função da temperatura corporal dos animais. De cada cavalo, amostras de sangue venoso foram coletadas antes do exercício (T0) e após o término da cavalgada (T1). As amostras foram analisadas através do i-STAT. Houve aumento $(\mathrm{P}<0,05)$ nos valores de $\mathrm{Hct}_{\text {, }} \mathrm{Na}^{+}, \mathrm{pH}, \mathrm{HCO}{ }_{3}^{-}$e BE nos animais do G20, após o término da cavalgada (T1). Após a cavalgada, os animais do $G 20$ apresentaram ainda diminuição na concentração de $K^{+} e$ de Cl. As alterações no equilíbrio ácido-base e hidroeletrolítico pós-cavalgada de $20 \mathrm{~km}$ resultou em alcalose metabólica hipoclorêmica. O esforço fisico de cavalgada de $20 \mathrm{~km}$ resultou em desequilibrios hidroeletroliticos e ácido-base significativos em cavalos da raça Mangalarga Marchador. Palavras-chave: gases sanguíneos, eletrólitos, equino, acidose, alcalose, cavalgada.

\section{INTRODUTION}

Physical exercise is responsible for alterations in various blood parameters (KIENZLE et al., 2006). Biochemical (TOLEDO et al., 2001), hydroelectrolytic (DI FILIPPO et al., 2009; DI FILIPPO et al., 2016), hormonal and metabolic (NOLETO et al., 2016) changes have been described in horses submitted to exercise of different intensities and durations. These changes occur as the organism attempts to adapt and supply the increased metabolic demand triggered by physical effort (PICCIONE et al., 2007) and are under most circumstances considered beneficial to the animal. However, physical exertion, when overly exhaustive or without proper training, can induce severe organic alterations, especially when the different tissues, organs or systems are not sufficiently adapted to support the different types of overload required of them without causing large changes in homeostasis (OGONOVSZKY et al., 2005). 
Lack of physical conditioning can be responsible for high serum concentrations of haptoglobin observed in horses after long-distance competitions (CYWINSKA et al., 2010). The persistence of the sharp increase in the enzymatic activity of $\mathrm{CK}$ and $\mathrm{LDH}$ has also been associated with lack of proper physical preparation of horses submitted to endurance competitions. Finally, declassification of horses during endurance riding events covering $100 \mathrm{~km}$ was associated with severe depletion of $\mathrm{K}^{+}$ions (ROSE et al., 1980).

In Brazil, the long distance transport (cavalcade) has in recent years become an important equestrian competition. In cavalcades, participation of horses of different breeds are common (MANSO FILHO et al., 2012). Participation of the Mangalarga Marchador breed in these events stands out due to these horses' rusticity and particularly their more comfortable marcha instead of trotting gait. However, the effects of cavalcade exercise on these animals are still unknown. The objective of this study was to investigate the effect of the physical effort of cavalcades covering $4 \mathrm{~km}, 8 \mathrm{~km}$ and $20 \mathrm{~km}$ on the acidbase and hydroelectrolytic balance in Mangalarga Marchador horses.

\section{MATERIALS AND METHODS}

The study involved 15 healthy Mangalarga Marchador geldings (age $6.2 \pm 1.2$ years, weight $420 \pm 58 \mathrm{~kg}$ ). Horses were distributed in three different groups according to the distance covered, namely, G4 $\left(4 \mathrm{~km}, 15 \mathrm{~km} \mathrm{~h}^{-1}\right)$, G8 $\left(8 \mathrm{~km}, 12 \mathrm{~km} \mathrm{~h}^{-1}\right)$, and G20 $\left(20 \mathrm{~km}, 12 \mathrm{~km} \mathrm{~h}^{-1}\right)$. All horses included in the study were privately owned and were prepared to participate in cavalcade by owners. These horses were trained two to four times a week for $30-60 \mathrm{~min}$ for more than three months.

Before the cavalcade, horses underwent a complete clinical examination. Body temperature, heart rate, and respiratory rate were recorded, and cardiac and pulmonary auscultation was carried out. Horses included had a normal clinical examination, and complete blood count, and biochemical parameters were performed.

Data were collected at a cavalcade held in Campos dos Goytacazes, Rio de Janeiro, Brazil on February 8, 2010 (2048'21'S, 40³8'52"W, altitude $13 \mathrm{~m}$ a.s.1.). The previously marked had a length of $20 \mathrm{~km}$, and was taken in a single day, without rest. Mean environmental temperature was $30.7^{\circ} \mathrm{C}$ and relative humidity was $79.3 \%$. Animals started the course together, but stopped after the predetermined distance according to the group. These weather indices were obtained from the agrometeorology database of the Center for Science and Technology of Norte Fluminense State University (CCT/UENF).

Blood samples $(7 \mathrm{~mL})$ were obtained in heparinized syringes from the jugular vein of each horse before the cavalcade (T0) and immediately after reaching the predetermined distance (T1). After collection, samples were immediately stored in ice and then analyzed with a portable clinical analyzer (I-Stat ${ }^{\circledR}$ Analyzer, Abbot Point of Care Inc., East Windsor, New Jersey, USA, with CG4 + and CG8 + cartridges) to determine the following variables: $\mathrm{pH}$, partial pressure of carbon dioxide $\left(p \mathrm{CO}_{2}\right)$, partial pressure of oxygen $\left(\mathrm{pO}_{2}\right)$, bicarbonate ion $\left(\mathrm{HCO}_{3}^{-}\right)$, base excess $(\mathrm{BE})$, lactate, hematocrit (Hct) and concentrations of sodium $(\mathrm{Na}+)$, potassium $(\mathrm{K}+)$ and chloride $(\mathrm{Cl}-)$. Blood $\mathrm{pH}$ measurements $(\mathrm{pH}, p \mathrm{O} 2$, and $p \mathrm{CO} 2)$ were corrected according to the rectal body temperature.

The experimental design was completely randomized and represented by the statistical model: $\mathrm{Y}_{\mathrm{ij}}=\mu+\alpha_{\mathrm{j}}+\mathrm{e}_{\mathrm{ij}}$, where $\mathrm{Y}_{\mathrm{ij}}=$ variables analyzed in the $\mathrm{i}$-th animal over the $\mathrm{j}$-th distance; $\mu=$ general average; $\alpha_{\mathrm{j}}=\mathrm{j}$-th distance; and $\mathrm{e}_{\mathrm{ij}}=$ random error, assuming a normal and uniform distribution $\mathrm{N} \sim\left(0, \delta^{2}\right)$. We tested the basic requirements for analysis of variance (normality and homoscedasticity) and analyzed the variables as repeated measures in time using the SAS program. Results are presented as mean \pm standard deviation. After the analysis of variance, the variables were submitted to the Tukey test. In all cases P-values $\leq 0.05$ were considered significant.

\section{RESULTS AND DISCUSSION}

All horses from G4, G8, and G20 managed to complete the cavalcade without abnormal signs. Mean values of acid-base and hydroelectrolytic balance in Mangalarga Marchador horses are reported in table 1 and 2 .

The values of $\mathrm{pH}, \mathrm{HCO}_{3}^{-}, \mathrm{BE}$, Hct and $\mathrm{Na}^{+}$concentrations in G20 were significantly higher $(P<0.05)$ than the pre-cavalcade values. Values of $\mathrm{K}^{+}$ and $\mathrm{Cl}^{-}$decrease only in $\mathrm{G} 20$ horses after cavalcade competition $(P<0.05)$.

Increases in the $\mathrm{pH}$ values of the animals in G20 were associated with loss of chloride ions in the sweat (Table 2). Because of the body's need to restore the balance of negative charges, the loss of chlorine ions in the sweat results in retention of the second most abundant ions in the organism, bicarbonate ions $\left(\mathrm{HCO}_{3}^{-}\right)$. In turn, the excess of $\mathrm{HCO}_{3}^{-}$triggers hypochloremic metabolic alkalosis 
Table 1 - Mean \pm s.d. values of venous $\mathrm{pH}, \mathrm{pCO}_{2}, \mathrm{pO}_{2}, \mathrm{HCO}_{3}{ }^{-}$, base excess and lactate concentration of Mangalarga Marchador horses before (T0) and after (T1) a cavalcade of 4,8 and $20 \mathrm{~km}$.

\begin{tabular}{|c|c|c|c|}
\hline \multirow{2}{*}{ Parameters } & \multirow{2}{*}{ Groups } & & \\
\hline & & T0 & $\mathrm{T} 1$ \\
\hline \multirow{3}{*}{$\mathrm{pH}$} & G4 & $7.41 \pm 0.00 \mathrm{Aa}$ & $7.42 \pm 0.00 \mathrm{Aa}$ \\
\hline & G8 & $7.41 \pm 0.00 \mathrm{Aa}$ & $7.41 \pm 0.00 \mathrm{Aa}$ \\
\hline & G20 & $7.40 \pm 0.01 \mathrm{Ba}$ & $7.46 \pm 0.02 \mathrm{Aa}$ \\
\hline \multirow{3}{*}{$p \mathrm{CO}_{2}$} & G4 & $42.67+1.64 \mathrm{Aa}$ & $44.21 \pm 0.81 \mathrm{Aa}$ \\
\hline & G8 & $43.48 \pm 1.84 \mathrm{Aa}$ & $44.09 \pm 0.72 \mathrm{Aa}$ \\
\hline & G20 & $44.64 \pm 2.38 \mathrm{Aa}$ & $45.32 \pm 1.79 \mathrm{Aa}$ \\
\hline \multirow{3}{*}{$p \mathrm{O}_{2}$} & G4 & $35.89 \pm 0.62 \mathrm{Aa}$ & $37.19 \pm 0.57 \mathrm{Aa}$ \\
\hline & G8 & $34.95 \pm 0.52 \mathrm{Aa}$ & $35.89 \pm 0.62 \mathrm{Aa}$ \\
\hline & G20 & $32.40 \pm 3.78 \mathrm{Aa}$ & $38.00 \pm 4.06 \mathrm{Aa}$ \\
\hline \multirow{3}{*}{$\mathrm{HCO}_{3}$} & G4 & $24.06 \pm 2.10 \mathrm{Aa}$ & $26.70 \pm 3.00 \mathrm{Ab}$ \\
\hline & G8 & $23.26 \pm 2.00 \mathrm{Aa}$ & $26.36 \pm 1.20 \mathrm{Ab}$ \\
\hline & G20 & $23.70 \pm 1.10 \mathrm{Ba}$ & $32.64 \pm 4.43 \mathrm{Aa}$ \\
\hline \multirow{4}{*}{ Base excess $\left(\mathrm{mmol} \mathrm{L}^{-1}\right)$} & G4 & $4.81 \pm 0.70 \mathrm{Aa}$ & $6.96 \pm 0.84 \mathrm{Ab}$ \\
\hline & G8 & $4.98 \pm 1.16 \mathrm{Aa}$ & $5.06 \pm 1.42 \mathrm{Ab}$ \\
\hline & G20 & $4.60 \pm 1.34 \mathrm{Ba}$ & $10.00 \pm 3.08 \mathrm{Aa}$ \\
\hline & G4 & $0.63 \pm 0.43 \mathrm{Aa}$ & $0.68 \pm 0.67 \mathrm{Ab}$ \\
\hline \multirow[b]{2}{*}{ Lactate $\left(\mathrm{mmol} \mathrm{L}^{-1}\right)$} & G8 & $0.82 \pm 0.59 \mathrm{Aa}$ & $0.89 \pm 0.22 \mathrm{Aa}$ \\
\hline & G20 & $0.80 \pm 0.53 \mathrm{Aa}$ & $0.86 \pm 0.52 \mathrm{Aa}$ \\
\hline
\end{tabular}

Means followed by different capital letters in rows differ significantly between times (Tukey test at $\mathrm{P}<0.05$ );

Means followed by different lowercase letters in columns differ significantly between groups (Tukey test at $\mathrm{P}<0.05$ ).

(DAY, 2002). According to JOHNSON (1995), this alkalosis is an important clinical complication in the exhaustion syndrome and in cases of exertional rhabdomyolysis. These affirmations are corroborated by the results reported in tables 1 and 2 . The animals in G20 after the exercise (T1) presented a significant decrease $(P<0.05)$ in the blood concentration of $\mathrm{Cl}^{-}$ and a concomitant increase in $\mathrm{HCO}_{3}^{-}$and $\mathrm{BE}$.

Results observed in horses after cavalcade of $20 \mathrm{~km}$ (T1) were similar to the results reported by ROSE et al. (1979) and DI FILIPPO et al. (2009) in horses after endurance competition and by MARTINS et al. (2016) after marcha competition. However, WATANABE et al. (2006), evaluating Arabian horses submitted to high-speed treadmill exercise, and SILVA et al. (2013), studying Quarter horses participating in barrel races, observed metabolic acidosis. According to both groups of authors, the metabolic alteration was due to the diffusion of $\mathrm{H}^{+}$ and lactate ions produced by the muscle cells to the bloodstream. The energy demands of muscle cells under moderate to high intensity exercises, unlike in cavalcade and endurance events, is maintained predominantly by anaerobic metabolism of glucose, resulting in buildup of $\mathrm{H}^{+}$and lactate ions in the muscle cells with consequent development of blood acidemia. According to AGUILERA-TEJERO et al. (2000), consumption of $\mathrm{HCO}_{3}^{-}$in the process of lactic acid buffering, caused by anaerobic metabolism, also contributed to blood acidemia.

The main organs involved in regulating the acid-base balance are lungs and kidneys. Through changes in the blood $\mathrm{pH}$, the respiratory compensations occur almost immediately, altering the $p \mathrm{CO}_{2}$ (ROBINSON, 2004). Nevertheless, compensatory respiratory response only allows the correction of slight disturbances and occurs for a brief period. Over the long run, regulation of acid-base balance requires excretion of $\mathrm{H}^{+}$ions and retention of bicarbonate ions by the kidneys, as described by FETTMAN (2004). 
Table 2 - Mean \pm s.d values of hematocrit, $\mathrm{Na}^{+}, \mathrm{K}^{+}$and $\mathrm{Cl}^{-}$of Mangalarga Marchador horses before (T0) and after (T1) a cavalcade of 4, 8 and $20 \mathrm{~km}$

\begin{tabular}{|c|c|c|c|}
\hline \multirow{2}{*}{ Parameters } & \multirow{2}{*}{ Groups } & & \\
\hline & & T0 & $\mathrm{T} 1$ \\
\hline \multirow{3}{*}{ Hematocrit (\%) } & G4 & $34 \pm 1.27 \mathrm{Aa}$ & $34 \pm 1.27 \mathrm{Ab}$ \\
\hline & G8 & $33 \pm 1.12 \mathrm{Aa}$ & $34 \pm 1.20 \mathrm{Ab}$ \\
\hline & G20 & $34 \pm 0.97 \mathrm{Ba}$ & $41 \pm 1.46 \mathrm{Aa}$ \\
\hline \multirow{3}{*}{$\mathrm{Na}^{+}\left(\mathrm{mmol} \mathrm{L}^{-1}\right)$} & G4 & $135.8 \pm 2.5 \mathrm{Aa}$ & $136.8 \pm 1.7 \mathrm{Ab}$ \\
\hline & G8 & $137.0 \pm 4.5 \mathrm{Aa}$ & $139.6 \pm 5.2 \mathrm{Ab}$ \\
\hline & G20 & $139.4 \pm 1.5 \mathrm{Ba}$ & $142.0 \pm 2.9 \mathrm{Aa}$ \\
\hline \multirow{3}{*}{$\left.\mathrm{K}^{+}(\mathrm{mmol} \mathrm{L})^{-1}\right)$} & G4 & $3.78 \pm 0.25 \mathrm{Ab}$ & $3.74 \pm 0.28 \mathrm{Ab}$ \\
\hline & G8 & $3.78 \pm 0.25 \mathrm{Ab}$ & $3.68 \pm 0.52 \mathrm{Ab}$ \\
\hline & G20 & $4.02 \pm 0.16 \mathrm{Aa}$ & $3.74 \pm 0.25 \mathrm{Ba}$ \\
\hline \multirow{3}{*}{$\mathrm{Cl}^{-}\left(\mathrm{mmol} \mathrm{L}^{-1}\right)$} & G4 & $101.2 \pm 1.3 \mathrm{Aa}$ & $100.6 \pm 2.5 \mathrm{Aa}$ \\
\hline & G8 & $104.2 \pm 4.9 \mathrm{Aa}$ & $101.6 \pm 2.0 \mathrm{Aa}$ \\
\hline & G20 & $103.4 \pm 4.5 \mathrm{Aa}$ & $98.4 \pm 3.6 \mathrm{Bb}$ \\
\hline
\end{tabular}

G4, 4km; G8, 8km; G20, 20km.

Means followed by different capital letters in rows differ significantly between times (Tukey test at $\mathrm{P}<0.05$ );

Means followed by different lowercase letters in columns differ significantly between groups (Tukey test at $\mathrm{P}<0.05$ ).

In line with these findings, the results in table 1 show changes in $p \mathrm{CO}_{2}$ and $p \mathrm{O}_{2}$ post-cavalcade of $20 \mathrm{~km}(\mathrm{G} 3)$; however, the differences were statistically significant $(P>0.05)$. These findings indicated respiratory acidosis, which added to metabolic alteration, is called metabolic alkalosis with respiratory compensation. That respiratory modification is common in sporting animals when faced with metabolic alkalosis (DI FILIPPO et al., 2009), and is a reflection of the animals' organic health.

No significant increase was observed in the lactate concentrations of the animals in the three groups $(P>0.05)$. These results differ from those reported in Quarter horses after barrel racing (SILVA et al., 2013) and team roping competition (CAIADO et al., 2011). Sharp increase in the lactate concentration in these two events was associated with metabolic demands of high-intensity effort, predominantly anaerobic. Lactate is considered a valuable substrate, with a significant role in producing energy for the myocardium, non-contracting muscles and even the brain (PÖSÖ, 2002). After the end of physical exertion (the period when $\mathrm{O}_{2}$ level is low), the lactate produced by the anaerobic metabolism is converted into glucose by the liver. In this way, lactate is removed from the bloodstream, serving as a beneficial energy substrate instead of acidifying the blood (WASSERMAN et al., 1991). Finally, the increase in the lactate values is expected after any type of exercise, because all the energy sources are activated (McGOWAN, 2008). However, this increase depends mainly on the intensity and duration of the physical effort (PÖSÖ, 2002). Based on these findings and the results of this study, the lactate values observed after the competition indicated that cavalcade exercise is not physically very demanding of the animals and allowed the organism to metabolize the lactate produced.

Increase in the hematocrit values presented by the animals of G20 after cavalcade was attributed to hemoconcentration resulting from loss of liquids from sweating, water losses from hyperventilation and passage of water from the dilated vascular bed to the hyperosmotic muscle in action (JOHNSON, 1995). Hemoconcentration can also be associated with the larger entry of erythrocytes in the bloodstream as a result of spleen contraction, a common reaction in horses. According to BABUSCI \& LÓPEZ (2007), spleen has capacity to store about $50 \%$ of the volume of erythrocytes in the body and its contraction can raise the hematocrit level from between 32 and $42 \%$ at rest to between 60 and $70 \%$ during exercise. The release of these erythrocytes into the bloodstream can be related to the level of stress generated by exercise, 
responsible for releasing adrenaline, which acts on the deposits of erythrocytes in the spleen, inducing their release (McGOWAN, 2008).

Higher Hct values observed in horses after cavalcade competition of $20 \mathrm{~km}$ were similar to the results reported in Mangalarga Marchador horses after official marcha tests (DI FILIPPO et al., 2016) and in many other studies of horses of different breeds involved in a variety of equestrian competitions (SNOW et al., 1982; KOWAL et al., 2006).

Increase in $\mathrm{Na}^{+}$concentration observed in the horses of G20 after cavalcade was similar to that detected in other investigation during endurance competitions of $60 \mathrm{~km}$ (DI FILIPPO et al., 2009) and $80 \mathrm{~km}$ (SNOW et al., 1982). According to FERRAZ et al. (2010), a possible mechanism to explain the elevation of serum concentrations of sodium is the exchange of ions and water that occurs between the active and inactive muscles. Dehydration increases the renal reabsorption of sodium so as to maintain the osmotic balance (MARTINS et al., 2005). However, the sodium levels of Arabian and Pantaneiro horses declined after a cavalcade competition covering 62km (MARTINS et al., 2004). The authors associated this result with the loss of sodium from sweating. Finally, Mangalarga Marchador horses submitted to marcha tests (FOLADOR et al., 2014; MARTINS et al., 2016), did not show changes in sodium levels. According to the authors, the concentrations of sodium remained relatively normal because an equivalent volume of fluid was lost and because marcha exercise has shorter duration and slower speed than endurance exercise (such as cavalcade).

The concentration of $\mathrm{K}^{+}$in the blood declined after the cavalcade in the animals of G3. In another study, similar findings were associated with the loss of this element in the sweat and renal reabsorption of sodium at the cost of excretion of potassium and hydrogen ions (MARTINS et al., 2005). DI FILIPPO et al. (2009) also reported that Arabian horses showed lower serum concentration of $\mathrm{K}^{+}$after an endurance competition of $60 \mathrm{~km}$. Losses of potassium during exercise have a significant influence on horses' performance (SNOW et al., 1982). Reduction of levels of $\mathrm{K}^{+}$can result in weakness, reduced intestinal motility, paralytic ileum and even alterations in the electrocardiographic trace (DAY, 2002).

\section{CONCLUSION}

Physical exertion during cavalcade competition promoted hydroelectrolytic and acidbase imbalances in Mangalarga Marchador horses after concluding a course with length of $20 \mathrm{~km}$.
Metabolic alkalosis triggered was due to the loss of $\mathrm{Cl}^{-}$ions in the sweat and consequent increase in bicarbonate retention by the kidneys. In turn, courses of 4 and $8 \mathrm{~km}$ did not cause hydroelectrolytic or acidbase imbalance in Mangalarga Marchador horses.

\section{BIOETHICS AND BIOSSECURITY COMMITTEE APPROVAL}

This study was approved by the Ethics Committee on Animal Use of Universidade Estadual do Norte Fluminense Darcy Ribeiro (UENF), Rio de Janeiro, Brazil (protocol number 304).

\section{REFERENCES}

BABUSCI, M.; LÓPEZ, E. F. Sistema cardiovascular. In: BOFFI, F. M. Fisiologia del ejercicio em equinos. Buenos Aires: InterMédica, 2007. p.123-132.

CAIADO, J. C. C. et al. Influence of physical exercise on serum activities of AST and CK and plasma concentration of lactate in Quarter horses submitted to team roping. Pesquisa Veterinária Brasileira, v.31, n.5, p.452-458, 2011. Available from: <http://www.scielo.br/ scielo.php?script=sci_arttext\&pid=S0100-736X2011000500014>. Accessed: Mar. 16, 2016

CYWINSKA, A. et al. Acute phase protein concentrations after limited distance and long distance endurance rides in horses. Research in Veterinary Science. v.93, n.3, p.1402-1406, 2012. Available from: $<$ http://www.ncbi.nlm.nih.gov/pubmed/22390917>. Accessed: Mar. 16, 2016.

DAY, T. K. Blood gas analysis. The Veterinary Clinics of North America: Small Animal Practice, v.32, n.5, p.1031-1048, 2002. Available from: <https://www.ncbi.nlm.nih.gov/pubmed/12380163>. Accessed: Mar. 16, 2016

DI FILIPPO, P. A. et al. Changes in electrolytes and blood gases in Arabian horses during $60 \mathrm{~km}$ endurance race. Ciência Animal Brasileira, v.10, n.3, p.840-846, 2009. Available from: $<$ http://revistas. bvs-vet.org.br/cab/article/view/7096>. Accessed: Mar. 16, 2016.

DI FILIPPO, P. A. et al. Gender differences - induced changes in serum hematologic and biochemical variables in Mangalarga Marchador horses after a marcha gait competition. Journal of Equine Veterinary Science, v.43, p.18-22, 2016. Available from: <http://www.j-evs.com/ article/S0737-0806(16)30036-3/pdf>. Accessed: May. 29, 2016.

FERRAZ, G. C. et al. The workload and plasma ion concentration in a training match session of high-goal (elite) polo ponies. Equine Veterinary Journal, v.42, suppl.38, p.191-195, 2010. Available from: $<$ http://www. ncbi.nlm.nih.gov/pubmed/21059005>. Accessed: Mar. 16, 2016.

FETTMAN, M. J. Fluid and electrolyte metabolism. In: THRALL, M. A. et al. Veterinary hematology and clinical chemistry. Philadelphia: Lippincott Williams \& Wilkins, 2004. p.329-355.

FOLADOR, J. C. et al. Serum concentration of sodium, potassium and calcium in Mangalarga Marchador horses after physical exercise. Archives of Veterinary Science, v.19, n.2, p.60-68, 2014. Available from: $<$ http://ojs.c3sl.ufpr.br/ojs/index.php/veterinary/article/view/34143>. Accessed: Mar. 16, 2016. 
JOHNSON, P. J. Electrolyte and acid-base disturbances in the horse. Clinical Pathology, v.11, n.3, p.491-514, 1995. Available from: $<$ http:// www.ncbi.nlm.nih.gov/pubmed/8925422>. Accessed: Mar. 16, 2016.

KIENZLE,E. etal. Doubleblind placebocontrolled vitaminEorselenium supplementation of Sport horses with unspecified muscle problems. JournalNutrition,v.136,n.7,p.2045-2047,2006.Availablefrom: $<$ http:// www.scielo.br/scielo.php?script=sci_nlinks\&ref=000099\&pid=S0100736X201100090000600011\&lng-pt>. Accessed: Mar. 16, 2016.

KOWAL, R. J. et al. Evaluation of hematologic values in thoroughbred (PSI) horses (Equus caballus) submitted to effort tests on treadmill. Revista Brasileira Ciência Veterinária, v.13, p.25-31, 2006. Available from: <http://www.uff.br/rbcv/ojs/index.php/rbcv/article/ view/447>. Accessed: Mar. 16, 2016.

MANSO FILHO, H. C. et al. Evaluation of heart rate and physical effort in athlete horses by the use of a frequency meter. Ciências Veterinária dos Trópicos, v.15, p.41-48, 2012. Available from: $<$ http://www.rcvt.org.br/volume15/Revista \%20CVT\%20Volume\%20 15\%20pag\%20de\%206.pdf $>$. Accessed: Mar. 16, 2016.

MARTINS, C. B. et al. Biochemical parameters in horses before and after endurance competition. Revista Brasileira de Ciências Veterinárias, v.12, n.1/3, p.62-65, 2005. Available from: <http://www.uff.br/rbcv/ojs/ index.php/rbcv/article/view/525>. Accessed: Mar. 16, 2016.

MARTINS, E. A. N. et al. Serum concentrations of urea, creatinine, sodium, potassium and calcium of the Pantaneiro and Arabian equines submitted to prolonged low intensity exercise in Mato Grosso State (cavalcade) - Brazil. Revista Brasileira de Ciências Veterinárias, v.11, n.1/2, pp. 32-36, 2004. Available from: <http://revistas.bvs-vet. org.br/rbcv/article/view/16682>. Accessed: Mar. 16, 2016.

MARTINS, L. P. et al. Effect of marcha exercise on serum electrolytes and acid base balance in Mangalarga Marchador horses. Journal of Equine Veterinary Science, v.49, p.108-112, 2016. Available from: $<$ http://www.j-evs.com/article/S0737-0806(16)30404-X/fulltext>. Accessed: Nov. 29, 2016.

Mc GOWAN, C. Clinical pathology in the racing horse: the role of clinical pathology in assessing fitness and performance in the racehorse. Veterinary Clinics of North America: Equine Practice, v.24, p.405-421, 2008. Available from: <http://www.ncbi.nlm.nih. gov/pubmed/18652962>. Accessed: Mar. 16, 2016.

NOLETO, P. G. et al. Effect of a $130 \mathrm{~km}$ endurance ride on the serum biochemical profiles of Mangalarga Marchador horses. Journal of Equine Veterinary Science, v.39, p.7-11, 2016. Available from: $<$ http://www.j-evs.com/article/S0737-0806(15)00512-2/abstract>. Accessed: Mar. 16, 2016

OGONOVSZKY, H. et al. The effects of moderate, strenuous, and overtraining on oxidative stress markers and DNA repair in rat liver. Canadian journal of applied physiology, v.30, n.2, p.186-195, 2005.
Available from: <http://www.ncbi.nlm.nih.gov/pubmed/15981787>. Accessed: Mar. 16, 2016.

PICCIONE, G. et al. Haematological response to different workload in jumper horses. Bulgarian Journal of Veterinary Medicine, v.10, p.21-28, 2007. Available from: <http://www. scielo.br/scielo.php?script $=$ sci nlinks\&ref $=000102 \&$ pid $=$ S18096891201300020000800024\&lng=en>. Accessed: Mar. 16, 2016.

PÖSÖ, A. R. Monocarboxylate transporters and lactate metabolism in equine athletes: a review. Acta Veterinaria Scandinaviaca, v.43, p.63-74, 2002. Available from: <http://www.ncbi.nlm.nih. gov/pmc/articles/PMC1764192/>. Accessed: Mar. 16, 2016.

ROBINSON, N. E. Homeostase ácido-básica. In: CUNNINGHAM, J. G. Tratado de fisiologia veterinária. Rio de Janeiro: Guanabara Koogan, 2004. p.539-550.

ROSE, R. J. et al. Blood-gas, acid-base and haematological values in horses during an endurance ride. Equine Veterinary Journal, v.11, n.2, p.56-59, 1979. Available from: <http://www.ncbi.nlm. nih.gov/pubmed/34511>. Accessed: Mar. 16, 2016.

ROSE, R. J. et al. Plasma and sweat electrolyte concentrations in the horse during long distance exercise. Equine Veterinary Journal, v.12, n.1, p.19-22, 1980. Available from: <http://www. ncbi.nlm.nih.gov/pubmed/7363879>. Accessed: Mar. 16, 2016.

SILVA, M.A. G. et al. Acid base balance in Quarter Horses performing Three Barrel Racing. Revista Brasileira de Medicina Veterinária, v.35, n.2, p.188-192, 2013. Available from: <http://www.rbmv.com. $\mathrm{br} /$ ?link=verart\&tipo=ID\&campo1=763>. Accessed: Mar. 16, 2016.

SNOW, D. H. et al. Alterations in blood, sweat, urine and muscle composition during prolonged exercise in the horse. Veterinary Record, v.110, p.377-384, 1982. Available from: <http://www. ncbi.nlm.nih.gov/pubmed/7080430>. Accessed: Mar. 16, 2016.

TOLEDO, P. S. et al. Serum activities of aspartate aminotransferase, creatine kinase, gamma glutamyltransferase, lactate dehydrogenase and glycaemia in thoroughbred horses submitted to exercise of different intensities. Revista Brasileira de Ciências Veterinárias, v.8, p.73-77, 2001. Available from: <file://C:/Users/HV/Downloads/1200-4418-1SM\%20(1).pdf>. Accessed: Mar. 16, 2016.

WASSERMAN, D. H. et al. Regulation of hepatic lactate balance during exercise. Medicine and Science in Sports and Exercises, v.23, p.912-919, 1991. Available from: <http://www.ncbi.nlm.nih. gov/pubmed/1956264>. Accessed: Mar. 16, 2016.

WATANABE, $\mathrm{M}$. J. et al. Changes in arterial $\mathrm{pH}, \mathrm{P}_{\mathrm{O} 2}, \mathrm{P}_{\mathrm{CO} 2}$ and blood lactate concentration in Arabian horses during exercise on a high-speed treadmill. Arquivo Brasileiro de Medicina Veterinária eZootecnia, v.58, n.3, p.320326, 2006. Available from: $<\mathrm{http}: / \mathrm{www}$.scielo.br/scielo.php?script=sci artt ext\&pid=S0102-09352006000300006>. Accessed: Mar. 16, 2016. 